\title{
(Re-)orienting the Concept of Water Risk to Better Understand Inequities in Water Security
}

\author{
Catherine Fallon Grasham ${ }^{1 *}$, Katrina Jane Charles ${ }^{1}$ and Tilahun Geneti Abdi ${ }^{2}$ \\ ${ }^{1}$ Social Sciences Division, School of Geography and the Environment, University of Oxford, Oxford, United Kingdom, \\ ${ }^{2}$ Oromia Agricultural Research Institute, Addis Ababa, Ethiopia
}

OPEN ACCESS

Edited by:

C. T. Dhanya,

Indian Institute of Technology

Delhi, India

Reviewed by:

Timos Karpouzoglou,

Royal Institute of Technology, Sweden Jim Wright,

University of Southampton, United Kingdom

*Correspondence:

Catherine Fallon Grasham catherine.grasham@ouce.ox.ac.uk

Specialty section: This article was submitted to Water and Human Systems,

a section of the journal

Frontiers in Water

Received: 21 October 2021 Accepted: 31 December 2021

Published: 24 February 2022

Citation:

Grasham CF, Charles KJ and Abdi TG (2022) (Re-)orienting the Concept of Water Risk to Better Understand

Inequities in Water Security.

Front. Water 3:799515.

doi: 10.3389/frwa.2021.799515
As populations grow and climate patterns change, difficult trade-offs in water security must be made. Re-allocation of water resources and re-distribution of water security outcomes will inevitably raise questions of equity. Equity is a central component of water security but often underemphasised, hence we still lack nuanced insights to how equity is understood and operationalised by water managers and users. The concept of risk is increasingly used in water security policy and practise but has been weakly integrated with equity considerations. We offer a contextual study that explicitly unpacks risk and inequity in water security across multiple scales; we have analysed lived water experiences and their hydrosocial drivers in a major river basin in Ethiopia. This is based on 61 interviews from seven rural kebeles, government organisations at woreda, zonal, regional and federal level and local and international NGOs as well as 17 industrial water user surveys. With our findings, and drawing on existing studies, we offer a theoretical framework for embedding water risk in equitable water security considerations. We find that when water risk is (re-)oriented from a biophysical framing, towards one centred on water-related values, it can be suitably embedded within hydrosocial framings of water security. This approach offers unique insights into how inequities are understood, within uneven power and political dynamics, which is critical for interventions that seek to deliver more equitable water security and meet social development targets.

Keywords: water security, water risk, water values and ethics, poverty \& inequality, sustainable develop goals

\section{INTRODUCTION}

There are inequities in water security-the unfair distribution of water security risks and benefits-that exist on a spectrum and can be delineated across contexts. Even just considering water access, inequities exist across social divides in wealth and ethnicity (JMP, 2019). Inequities in water security are shaped by a combination of social and natural drivers, requiring an interdisciplinary approach to understand them. Natural endowments in water security are inherently unequal, due to the quantity and reliability of water resources, and frequency of water-related hazards (Dadson et al., 2017). Social structures can mediate or exacerbate these inequalities, leading to inequities. In arenas of water scarcity, water resources are often prioritised for economic activities to the detriment of social development through market mechanisms (Swyngedouw, 2009) and governance norms (Woodhouse and Muller, 2017). Inequity is acutely observed in developing countries where institutional arrangements to govern water security are weak (Hepworth et al., 2013), while Sustainable Development Goal (SDG) 6 calls for safe and affordable water for all, placing the poorest and most marginalised in the spotlight (UN, 2019a). 
Questions of equity will become more prominent within water security trade-off decisions in the future meaning that a holistic understanding and operation of water security is needed. As populations grow (UN, 2019b) and climate patterns change (IPCC, 2014), difficult trade-offs in water security will have to be made. Re-allocation of water resources and re-distribution of water security outcomes will inevitably raise equity issues. Hoekstra et al. (2018) have argued that equity is a central component of water security; equity is also a foundational principle of water justice (Boelens et al., 2018). However, we still lack nuanced and local perspectives on what this can mean in practise and how equity is understood differently by water managers and users.

The concept of risk is increasingly used in water security policy and practise but has been weakly integrated with equity considerations. Water security is complex, comprising multiple conceptual bases and often defined according to Grey and Sadoff (2007) as "an acceptable quantity and quality of water for health, livelihoods, ecosystems and production, coupled with an acceptable level of water-related risks to people, environments and economies." The operation of risk in water security has primarily been with a physical science framing, such as focusing on frequency and size of flood hazards, where risk is typically defined as: (hazard x exposure $\mathrm{x}$ vulnerability) (Nofal and Van De Lindt, 2020). This conceptualisation insufficiently explores what is at risk, for whom and to what degree, limiting the alignment of risk with equity. Drawing on existing scholarly work, and with a case study of the Awash River basin in Ethiopia, this paper reveals how equity and risk in water security are inherently interlinked through values and we highlight the inequitable lived experiences, perspectives and values of water security and the socio-natural processes that influence them.

We offer a conceptual framework for studying equity in water security, including the concept of water risk-understood with water-related values. This framework is a hydrosocial framing that enables the root causes of inequities in water security to be understood, particularly through the consideration of power and political arrangements. We begin with a discussion of existing frameworks that are used for studying water security, their differences, and limitations. We then expand on why our framework is necessary and relevant. Following this, we enter the case study of the Awash River basin in Ethiopia to further explain why our framework has been developed and to justify the essentiality of (re-)orienting the concept of water risk in terms of human values in hydrosocial studies of water equity. Finally, we conclude that water security interventions need to include waterrelated values and address water equity explicitly to meet social development targets.

\section{A SOCIO-NATURAL FRAMEWORK FOR STUDYING INEQUITIES IN WATER SECURITY}

Critiques of siloed water security research have highlighted the need for interdisciplinary studies (Zeitoun, 2011; Cook and Bakker, 2012; Lankford et al., 2013) which has supported a move towards hydrosocial and socio-hydrological approaches. While not completely divergent (Rusca and Di Baldassarre, 2019), there are significant differences between the two. First, hydrosocial approaches are exemplified by the hydrosocial cycle, developed by Linton and Budds (2014), that posits that water and society continually remake each other while putting society at the centre of water security enquiry, stressing the subjectivity of knowledge. Second, socio-hydrology approaches, originally proposed by Sivapalan et al. (2012), seek to integrate society in the examination of natural systems and have been criticised for focusing on engineering solutions with insufficient consideration of the complexity and irrationality of human behaviour (Wesselink et al., 2017), despite recent scholarly work that seeks to address this (e.g., Savelli et al., 2021) Hydrosocial approaches to studying water security are also not without limitations.

We propose a socio-natural framework (Figure 1) that is a bricolage of existing concepts and draws substantially on hydrosocial theory. Power and politics are central concepts in hydrosocial framings of water security (Bakker and Morinville, 2013; Woodhouse and Muller, 2017) and such approaches have revealed that uneven power relations play out through access to water (Swyngedouw, 2004). Power in the case of our framework is the ability to influence water security through socio-cultural (Crow and Sultana, 2002; Wutich et al., 2017), financial (Bues and Theesfeld, 2012), or political means (Strang, 2016). We broadly conceptualise "politics" as the institutional arrangements that govern water security as well as wider dynamics in political ecology and political economy, following Zwarteveen et al. (2017) who argue, "that water governance at heart is about political choices as to where water should flow; about the norms, rules and laws on which such choices should be based; about who is best able or qualified to decide about this; and about the kind of societal future such choices support." We also include scale as a crucial concept as water security manifests at different scales (Srinivasan et al., 2017), from the global (Wada et al., 2016) to national (Calow and Mason, 2014), city (Grasham et al., 2019; Truelove, 2019) and through to the intra-household level (Wutich et al., 2017).

Hydrosocial approaches have been criticised for understating the natural system (Wesselink et al., 2017) and we acknowledge this criticism with the inclusion of the concept of place in our framework. Ideas of place in the water security literature have been discussed extensively and we draw on Boelens et al. (2016) who developed the term "hydrosocial territories." Their definition of territories has a socio-natural conceptual underpinning: "Territories, although often considered natural, are actively constructed and historically produced through the interfaces amongst society, technology and nature." (Boelens et al., 2016). The idea of hydrosocial territories offers an interdisciplinary basis to study the relationship between inequities in water security mediated by geographical location. We will expand this conceptualisation further with case study evidence which reveals how intimately connected water security is to physical location.

At the centre of our framework we have equity. Equity is a philosophical concept with multiple interpretations. Perreault 


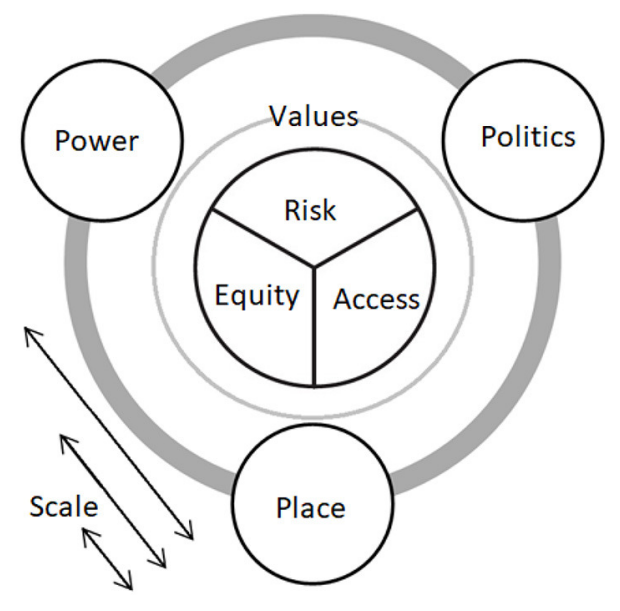

FIGURE 1 | Conceptual framework for evaluating inequities in water security.

(2014) has offered defining characteristics for thinking about equity in water governance which are useful for conceptualising equity in water security: "Equity is fairness. Equity is impartiality. Equity is something defined in law, and yet informed by deeper ethical principles. Equity is justice." In the same way as risk, ideas of equity are also centrally defined by values. When everyone's subjective values are met to avoid circumstances of unacceptable risk, it can be argued that water security is equitable. In the following section, we present our case study research from the Awash River basin that illustrates how our framework offers further insights into diverse understandings of inequities in water security.

Limitations in socio-hydrology and hydrosocial approaches partly stem from the way that they define water security, due to their differing epistemological positions (for good overviews of the current water security literature see: Zeitoun et al., 2016; Hoekstra et al., 2018). Hydrosocial approaches are grounded in constructivist approaches and tend to adopt definitions of water security based on the idea that water security is relational (Linton and Budds, 2014; Jepson et al., 2017). Socio-hydrology approaches to water security are underpinned by positivist notions of truth that lead to definitions of water security that can be quantified with objective measurement. Typically, Grey and Sadoff's (2007) definition is used in socio-hydrology approaches that centre on quantifiable indicators of water access and water risk. We lift the concept of water risk into our framework from socio-hydrology. Unusually for a hydrosocial study, we adopt Grey and Sadoff's definition of water security. This has been, in part, motivated by Yates et al. (2017) who highlight the importance of "cross-pollinating scholarship across debates on water and multiple ontologies."

\section{(Re-)orienting the Concept of Risk With Embedded Values}

Equity issues are easily overlooked in water security (Goff and Crow, 2014), depending on how risk and "acceptability" (or "tolerability") of risk are interpreted. Acceptability as a concept is problematic, commonly interpreted on an economic basis which implies cost-benefit analyses that determine that, "a risk is acceptable if the economic savings arising out of action to reduce a risk outweigh the cost of such action" (Hunter and Fewtrell, 2001). The risk approach to water security has been criticised for being reductionist and underemphasising equity, diversity, politics and sustainability (Zeitoun et al., 2016; Hoekstra et al., 2018). Inequities in water security will inevitably persist and this definition allows for an "acceptable" degree of inequity in water security after the SDGs are met.

As well as physical framings, the concept of risk has received significant scholarly attention from social science disciplines. The sociologist Giddens (1999) argued:

\footnotetext{
"There is no risk which can even be described without reference to a value. That value may be simply the preservation of human life, although it is usually more complex. When there is a clash of the different types of risk, there is a clash of values and a directly political set of questions."
}

Embedding values in risk has been done in other oft considered "physical" disciplines but is insufficiently explored in the arena of water security. For example, in the IPCC report (2014), climate scientists include in their definition of risk: "The potential for consequences where something of value is at stake and where the outcome is uncertain, recognising the diversity of values." Using Giddens' conceptualisation, we argue that social relations are inherent in the concept of risk, due to the fundamental relationship between risk and values. We know that water risk is socially reproduced (Oulahen, 2021), hence suitable for inclusion in hydrosocial studies. (Re-)orienting the concept from a physical to a social framing allows for risk to be embedded within hydrosocial studies.

Overall, risk is a central component of water security but has predominantly been omitted from hydrosocial studies since the concept was born from positivist epistemologies and physical sciences approach to water security. However, if the concept of risk is oriented to a social science conceptualisation, centring on water-related values, the concept of risk can be embedded within hydrosocial studies of water security. We locate this approach within the existing body of work that understands risk through qualitative methodologies and social constructivist epistemologies (e.g., Beck, 1992). This will allow for subjective and diverse interpretations of the "acceptability" of risk based on human experience rather than economic criteria. Given this, we include water-related values in our socio-natural framework and define them as principles that guide action towards water security by water users or water managers in public, private or community groups, the latter drawing from Koehler et al.'s (2018) cultural theory of water risk.

\section{RESEARCH DESIGN}

The case study draws on the Awash River basin in Ethiopia. As an endorheic basin, in a country where much of the rainfall is in the transboundary Blue Nile basin and therefore subject to international treaties (Yihdego et al., 2017), the Awash basin has 
been a focus for intensive industrial and agricultural development by the Government of Ethiopia (AwBA, 2017). Therefore, the Awash basin has high national economic significance. Water governance in the Awash is complicated as the river is divided by five of Ethiopia's regional states, while the main river channel is predominantly shared between the Oromia and Afar regions (Figure 2). Water resources in the basin are over-allocated (Gedefaw et al., 2018), with rapid urbanisation and expansion of irrigation and industry increasing demand. The climate is highly variable (Bekele et al., 2016) with climate change projected to lead to future reductions in water resources availability (Taye et al., 2018; Hirpa et al., 2019). Water policies and legal frameworks are poorly implemented (Mosello et al., 2015; Hailu et al., 2018) and stakeholder responsibilities are fragmented (Hailu et al., 2019).

The regions reflect different ethnic groups and climates. Agro-ecological zones range from moisture-reliable highlands in the upper basin to the arid lowlands downstream. The climate influences the nature of rural livelihoods with rainfed farming common in the highlands where rainfall variability is low, agro-pastoralism in the centre and predominantly pastoralist livelihoods in the lower basin where variability is high. The basin is highly prone to flood (Wondim, 2016) and drought (Edossa et al., 2010), and subject to deteriorating water quality (Degefu et al., 2013). The expanding saline Lake Beseka (Dinka, 2017) in the middle basin is of critical interest to policy makers as it is a source of water-related risks to land, water and human health (Kebede and Zewdu, 2019).

To unpack the nature and drivers of unequal water security, three woredas were selected for the application of social research methods across the upper, middle and lower basin to capture ethnic diversity and different agro-ecologies. In the upper basin, in the Oromia region, a woreda was selected close to Koka dam; in the lower basin a woreda in the Afar region near to Tendaho dam was chosen; and an ethnically diverse woreda in the middle basin, adjacent to Lake Beseka, that sits on the regional border was selected. Similarly to the ethnic differences, there are two main climate zones (Taye et al., 2018), with the middle basin site located on interface between them. These three areas correspond with the government's allocated water management areas within the basin (AwBA, 2017).

There has been insufficient exploration of inequity in water security in this context which is necessary since: (1) inequalities in water services have recently increased in Ethiopia (JMP, 2019) and (2) the new national water resources policy draft is

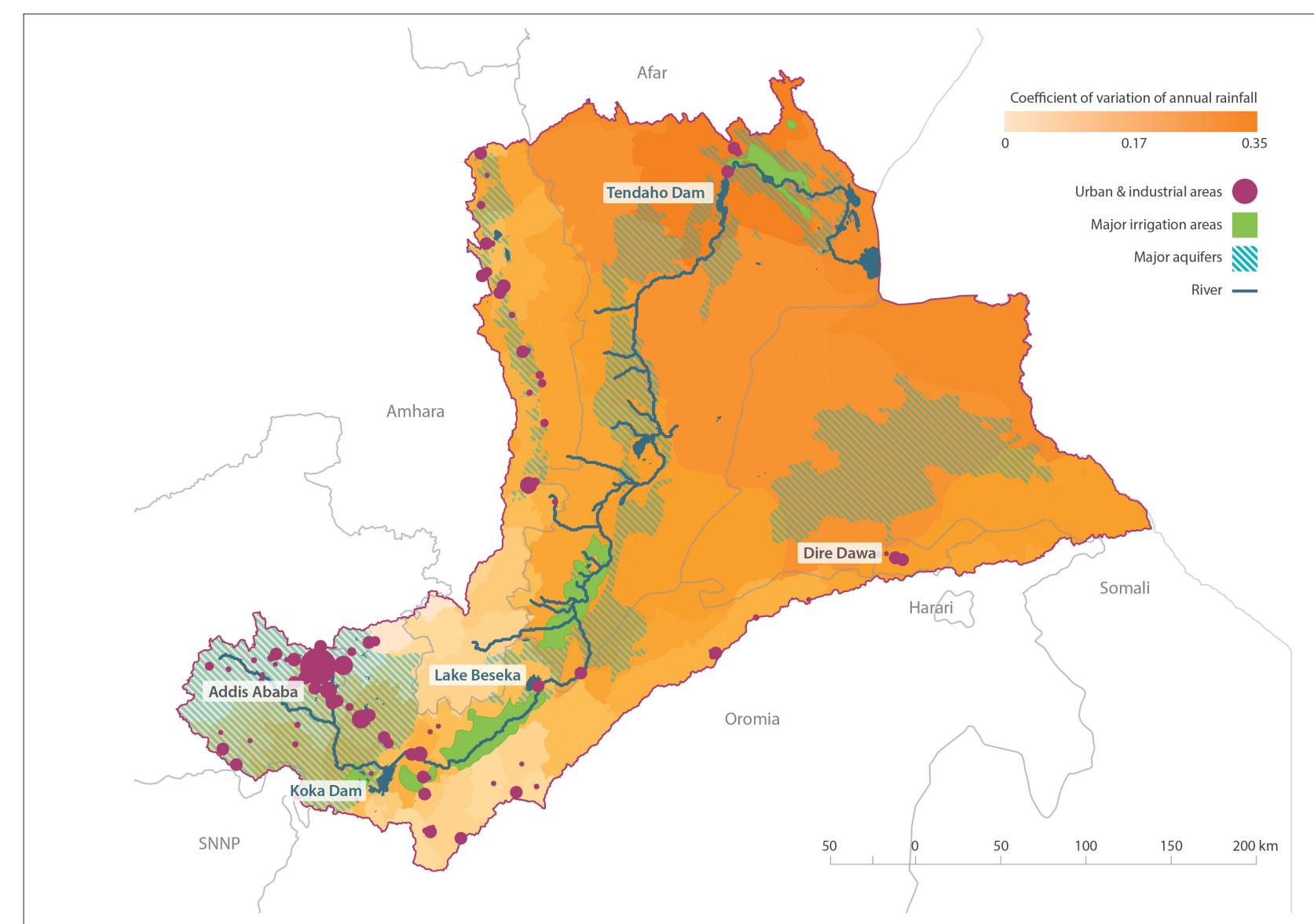

FIGURE 2 | Awash River basin, Ethiopia, highlighting key groundwater and surface water bodies. Climate variability ranges from high rainfall, low variability in the highlands, to low rainfall, high variability in the lowlands. Urban and industrial areas represent growing areas of water demand and pollution sources. 
considering recognising diverse values related to water. National policies focus on economic development as a priority (e.g., the second Growth and Transformation Plan, GTP-2), hence the focus of social research in the Awash River basin has tended to align with this and has less closely addressed equity issues. There have been studies on integrated water resources management (IWRM) (Mersha et al., 2016, 2018), water governance (Hailu et al., 2018, 2019; Hailu and Tolossa, 2020), perceptions of agricultural water management (Desalegn et al., 2006) and hydroeconomics (Borgomeo et al., 2018). We contribute to this body of knowledge with a focus on inequities in water security.

\section{Methods and Analysis}

Social research methods were used in three field visits to the Awash basin in 2018: Within the three woredas (administrative districts), seven kebeles (the lowest administrative unit) were selected for key informant interviews as well as complete enumeration of urban water utilities, industrial water users and systematically selected actors from selected government and international and national non-government organisations (Table 1).

Prior to fieldwork, ethical approval for this research was given through the departmental board of the Oxford University Central University Research Ethics Committee (CUREC). There was a team of two data collectors-one British female, and one Ethiopia male. There were uneven power relations between the field data collectors and participants and with this in mind, it was clearly stated what the benefits of the research would be. Informed verbal consent was given by each participant in this research on the basis that the data collected would be stored securely and that their responses would remain anonymous. None of the participants were actively incentivised or coerced in any way to engage with this research.

Interviews were conducted in rural kebeles selected from each woreda (14 male and 14 female, randomly selected with support from kebele officials). Interviews were secured with support from the kebele administration office. Key informant interviews ( $n$ $=33$ ) were conducted with government and non-government organisations including woreda-, zonal-, regional and federallevel administrations responsible for managing pastoralism, agriculture (rainfed and irrigation), water supply (rural and urban), health and disaster prevention \& preparedness. A mixed qualitative/quantitative industrial water user survey was used to collect values and perceptions of water security from large farms and factories $(n=17)$. The interview questions and industrial water user survey were piloted in Adama woreda (Oromia region, Awash River basin) in November 2017. The empirical evidence has been triangulated to enable a robust and reliable argument by reducing bias in the data with documentary analysis as well as through engagement with organisations in multiple and various fora since 2015.

NVivo was used to undertake systematic qualitative analysis of the empirical evidence to understand the inequity of access to water of an acceptable quality and differences in the lived experiences of water-related risks. The interviews were transcribed and translated where consent was given for recording. In cases where consent for recording was not given,
TABLE 1 | Overview of methods used in each woreda.

\begin{tabular}{ll}
\hline $\begin{array}{l}\text { Upstream woreda } \\
\text { Drought-prone kebele }\end{array}$ & $\begin{array}{l}\text { Predominant livelihood: rainfed cultivation of grain } \\
\text { crops (four interviews: two male, two female) }\end{array}$ \\
Lakeside kebele & $\begin{array}{l}\text { Predominant livelihood: fishing (four interviews: two } \\
\text { male, two female) }\end{array}$ \\
Flood-prone kebele & $\begin{array}{l}\text { Predominant livelihood: Irrigated agriculture (four } \\
\text { interviews: two male, two female) }\end{array}$ \\
Private, large-scale irrigated & $\begin{array}{l}\text { Two flower farms, two fruit and vegetable farms (4) } \\
\text { farms }\end{array}$ \\
Private factories & $\begin{array}{l}\text { Eight tanneries, one water bottling company (9) } \\
\text { State-owned farms }\end{array}$ \\
Interviews with NGOs & Catholic Mission (1) \\
Interviews with Woreda & Health; Land management; Agriculture and Natural \\
government offices & $\begin{array}{l}\text { Resources; Livestock and fisheries; Environment, } \\
\text { forestry and climate change; Disaster prevention } \\
\text { and preparedness commission (DPPC); Irrigation; } \\
\text { Water, minerals and energy (WME) (8) }\end{array}$
\end{tabular}

\section{Middle basin woreda}

Drought-prone kebele

Flood-prone kebele

Agro-pastoralist livelihoods (6)

Mixed crop-livestock systems: settled agro-pastoralists with irrigated smallholds (6)

Private farms (large-scale)

Private factories

$-(0)$

State-owned farms

One abattoir (1)

NGOs

Metehara sugarcane farm (1)

Child Fund, Rift Valley Initiative for Rural

Advancement (RIRA) (2)

Woreda Government Offices Disaster prevention and preparedness commission; Agriculture and Natural Resources; Irrigation; Water, minerals and energy (4)

\section{Downstream woreda}

Drought-prone kebele

Flood-prone kebele

Private farms

Pastoralists (6)

Private factories

Settled pastoralists - irrigating smallholders (6)

$-(0)$

State-owned farms

One salt factory (1)

NGOs

Tendaho sugarcane farm (1)

World Food Programme of the United Nations (WFP), United Nation's Children Fund (UNICEF) (2)

Others

Tendaho Dam Administration Office (1)

\section{Other stakeholder interviews}

Zonal government

administration offices

Municipal water utilities

Afar regional government offices

Oromia region

Federal
Zonal Administration Office, Zone 1, Afar; East Shewa DPPC office; East Shewa National Meteorological Agency (3)

Seven municipal water utilities across the basin (7)

Agriculture and pastoralism; DPPC Irrigation; Water Supply and Sanitation (4)

WME Bureau; Oromia DPPC (2)

Awash Basin Development Office, Upper Awash sub-branch, Adama; Awash Basin Development Office, lower Awash sub-branch, Dubti; National DPPC (3) detailed interview notes were used. We analysed the differences in experiences of water security between and within four groups of water managers that rely on water resources for different uses: private industries (farms and factories), state-owned sugarcane farms, urban water utilities and rural communities. 
Our methods and analysis identified the values of water users and managers that were being protected or harmed with water access and risk. Every effort was made by the researchers to ascertain local values by using methodological tools that allowed water users and managers to identify their own values. Moreover, the analysis was conducted with the researchers' subjectivity in mind in order to reduce as much cultural bias as possible. Following this, the exposure and vulnerability to hazards were characterised in nodes as well as water users and managers experiences of water access. Seeking to understand the institutional arrangements of water security, two nodes were created: (1) planning and controlling exposure and vulnerability to hazards; (2) water allocation and access.

\section{MULTI-SCALE LIVED EXPERIENCES OF UNEQUAL WATER SECURITY}

To evaluate the multi-scale and unequal lived experiences of water security in the Awash River basin, we started with identifying water users, water-related hazards and values, in order to determine vulnerability to water risk. Reported vulnerabilities to biophysical water hazards (drought, flood and seasonal variability) by water user are given in Table 2 . These were reported based on "normal" patterns of intra-annual climate and water vulnerability, as well as the most recent flood and drought event(s) that the respondent had experienced.

The results in Table 2 are given by month, with the two main annual rainy seasons, belg and kiremt. However, water users in the downstream woreda reported rain commonly only falling in July and August and the middle basin user reported rain during kiremt only. Water users have been divided into: (1) three rural communities: upstream, middle and downstream; (2) urban water utilities; (3) private fruit/vegetable farms; (4) private flower farms and (5) state-owned sugar farms. We also surveyed 11 private factories that reported no vulnerability to climate shocks or variability, hence have been excluded from Table 2.

There were reported temporal changes in water demand that shaped which water-related values were being put at risk. Higher demands on urban and rural water systems in the dry season meant that water needs were not being met. In rural areas, for example, scarcity of surface water for livestock meant that animals were sometimes watered using governmentmanaged, formal water supplies. Private fruit and vegetable farms had their highest demand in May and June due to little rainfall and the peak growing season. Since they are open-air farms, in the main rainy season (Kiremt, July-September), they reduced their river abstraction. Private flower farms, cultivating crops in had their peak abstraction rates from December to March, due to market demand. Despite not using rainwater for cultivation, their abstraction rates also reduced in the wet season.

Given that we define water-related values as, "principles that guide action towards water security by water users or water managers in public, private or community groups" we find that values are diverse across users. Private business users have 1 or
2 water-related values while members of rural communities have many, since so many areas of their lives are touched by, or depend on, water. Some of the values we have uncovered may appear obvious, nonetheless, it is essential to draw these out in order to garner a meaningful understanding of water risk.

The water-related values of water users and managers varied, closely aligned with their roles. The private farms and factories that we surveyed strived, above all, to be profitable, hence the primary water-related value expressed was that of secure water for productive purposes. When asked about their water use, $100 \%$ reported production processes first; only $40 \%$ reported drinking as a use of water, illustrating that drinking water was a less relevant water-related value than production. Unsurprisingly, the state-owned sugarcane farms in the three study sites placed the highest water-related value on sugarcane production, while urban water utilities prioritised the ability to deliver reliable and safe water supplies to urban communities.

Conceptualising these-seemingly obvious-water-using activities as water-related values is necessary and important to: (1) garner a meaningful understanding of water risk; (2) explore how water-related values are competing and; (3) to make comparisons across water user groups, about how inequities can be understood and re-distributed, especially in contexts with extreme inequities in water security. The latter is the case in the Awash River basin: rural communities are extremely water insecure, while private farms \& factories enjoy high levels of water security. Water-related values offer a common framework for understanding what drives decision making of water users towards water security.

Rural community members hold a diverse set of personal values that have a temporal dimension and drive waterand climate-related risk adaptation strategies. The values we uncovered centred on: (1) agency over livelihood, place, mobility, self-sufficiency and the ability to partake in cultural activities; (2) well-being in terms of physical and mental health, safety and food security; (3) a secure livelihood and (4) specific values held for children now and for the future. By placing the values of the water users and managers at the centre of the analysis allows the lived experiences in the Awash River basin to explain unequal water security. We juxtapose the competing values of urban water managers, industrial water users and rural dwellers in this dynamic context.

\section{Power}

Uneven socio-cultural, financial and political power relations shape the differences in lived experiences, and ideas of, water insecurity. Power dynamics play out across scales; there are differences between water management groups and inter and intra-household inequities. Some water users have more power than others to access water through higher financial capacity, stronger influence in decision-making and social privilege. This is highly influenced by drivers within the wider political economy in Ethiopia and the fact that there are ingrained intra-household gender roles and gender inequities in rural Ethiopia (Semela et al., 2019) that shape these differences in vulnerability. We reveal evidence for how unequal water security is, in part, socially produced through uneven power relations. 
TABLE 2 | Reported temporal changes recent extremes and recurrent water and climate-related hazards caused by expected and unexpected climate and water resources variability that resulted in exposure and vulnerability to water risk.

\begin{tabular}{|c|c|c|c|c|c|c|c|c|c|c|}
\hline \multirow[t]{2}{*}{ Water users } & \multirow[t]{2}{*}{ Type of hazard } & \multicolumn{4}{|c|}{ Long dry season } & \multicolumn{2}{|r|}{ BELG } & \multirow{2}{*}{$\begin{array}{l}\text { DRY\&HOT } \\
\text { June } \\
\end{array}$} & \multicolumn{2}{|c|}{ KIREMT } \\
\hline & & Oct & Nov & \begin{tabular}{|l|l|} 
Dec & Jan \\
\end{tabular} & Feb & Mar Apr & May & & July Aug & Sept \\
\hline \multirow[t]{2}{*}{ Upstream rural communities } & Flood & & \multicolumn{2}{|c|}{$\begin{array}{c}\text { Occasional } \\
\text { (unexpected) dry } \\
\text { season flooding }\end{array}$} & & & & $\begin{array}{l}\text { Unexpected } \\
2018 \text { flood } \\
\text { destroyed } \\
\text { crops }\end{array}$ & $\begin{array}{l}\text { Annual } \\
\text { (expected) } \\
\text { flooding }\end{array}$ & \\
\hline & Drought & & & & & & & & \multicolumn{2}{|c|}{$\begin{array}{l}\text { Inter-annual shortage of } \\
\text { rainfall - most severe } \\
\text { recent drought } \\
\text { reported 2015/16 }\end{array}$} \\
\hline \multirow[t]{3}{*}{ Middle basin rural communities } & Flood & \multicolumn{6}{|c|}{ Occasional (unexpected) dry season flooding that destroys crops, fodder } & $\begin{array}{l}\text { Unexpected } \\
2018 \text { flood } \\
\text { destroyed } \\
\text { crops }\end{array}$ & $\begin{array}{c}\text { Annual } \\
\text { (expected) } \\
\text { flooding }\end{array}$ & \\
\hline & Drought & & & & & & & & \multicolumn{2}{|c|}{$\begin{array}{l}\text { Inter-annually recurrent } \\
\text { below average rainfall } \\
\text { (drought) }\end{array}$} \\
\hline & Seasonal variability & \multicolumn{6}{|c|}{ Water scarcity } & & & \\
\hline \multirow[t]{2}{*}{ Downstream rural communities } & Drought & & & & & & \multicolumn{2}{|l|}{$\begin{array}{l}\text { Cultivation of irrigated } \\
\text { agriculture. Water not } \\
\text { always available in the } \\
\text { irrigation canal (2015, } \\
\text { completely dry) }\end{array}$} & & \\
\hline & Seasonal variability & \multicolumn{5}{|c|}{ Water scarcity } & \multicolumn{2}{|l|}{$\begin{array}{l}\text { Most difficult months } \\
\text { for water access (due } \\
\text { to scarcity) }\end{array}$} & \multicolumn{2}{|c|}{ Water Scarcity } \\
\hline \multirow[t]{2}{*}{ Urban water utilities } & Surface water & & & & & \multicolumn{4}{|c|}{$\begin{array}{l}\text { Surface water infrastructure blocked by debris in the river } \\
\text { washed down from upstream }\end{array}$} & \\
\hline & Groundwater & \multicolumn{4}{|c|}{ Groundwater levels decrease } & & & & \multicolumn{2}{|c|}{$\begin{array}{l}\text { Salinity of groundwater } \\
\text { increases }\end{array}$} \\
\hline $\begin{array}{l}\text { Privately owned fruit and vegetable } \\
\text { farms }\end{array}$ & $\begin{array}{l}\text { Hazards reported } \\
\text { from } 2018\end{array}$ & & & $\begin{array}{l}\text { Frost } \\
\text { destroyed } \\
\text { crops }\end{array}$ & & $\begin{array}{c}\text { River level was too } \\
\text { low and crops } \\
\text { were lost as a } \\
\text { result }\end{array}$ & & & & \\
\hline \multirow[t]{3}{*}{ State-owned sugar farms } & Flood & & & & & & & & \multicolumn{2}{|c|}{$\begin{array}{c}\text { Annual (expected) } \\
\text { flooding that varies in } \\
\text { intensity }\end{array}$} \\
\hline & Drought & & & & & \multicolumn{3}{|c|}{$\begin{array}{l}\text { Inter-annually recurrent below average rainfall (drought) affecting water } \\
\text { availability (up to } 25-30 \% \text { reduction in cultivation in 2015/16) }\end{array}$} & & \\
\hline & Seasonal hazards & & & & & & \multicolumn{2}{|l|}{$\begin{array}{l}\text { High evaporation } \\
\text { and low rainfall }\end{array}$} & & \\
\hline Privately owned flower farms & Seasonal hazards & & & & & & & & $\begin{array}{r}\text { Decrease in } \\
\text { water } \mathrm{q}\end{array}$ & \\
\hline
\end{tabular}




\section{Financial Power}

Provision of safe and sufficient water to communities is the highest water value of providers but they lacked financial power to make investments to improve service delivery. In general, across the Awash River basin, government water supplies were reported to be intermittent and of poor quality. This was reported by urban water utilities, rural water service providers and private industries that were accessing water from government water supplies. In most rural and urban cases, water was not being treated before being distributed to community members, despite elevated fluoride and likely faecal contamination.

The ability of water users to be water secure is strongly influenced by their power to invest in water treatment technologies. Private factories and flower farms in the Awash basin were generally water secure; they had good access to water and their production processes were not vulnerable to water risks meaning that their values were not being compromised by water insecurity. Factories typically had deep, reliable boreholes and the flower farms were using raw river water and sophisticated water treatment systems. However, government water supply organisations lacked similar power and were forced to provide poor quality water to rural and urban communities.

Peoples' understanding of inequity in water security was strongly grounded in ideas of unfairness and injustice. Upstream, the groundwater resources were highly contaminated with fluoride. Most people were drinking untreated groundwater with unpleasant health impacts including browning of teeth, scoliosis of the spine and bone deformities. Next to the main town, a water bottling factory was abstracting groundwater, treating it to safe drinking water standards, bottling it and selling it for profit. The town residents refused to buy bottled water from this factory due to the unfairness they felt that they could not access safe water whereas a private company could. This forced the company to transport their product outside of the area. Here, a company, with enough financial power was able to access sufficient water and treat it to a high quality, in an area where the physical water resources were of poor quality and a less powerful water manager, the government water provider, was unable to.

Water users and managers were adapting to different degrees to access water and mitigate water-related risks. People living in rural areas were constrained in protecting their values by a lack of agency to engage in alternative income-generating activities. In some cases, this resulted in maladaptation producing adverse risks. Research participants from rural areas that reported having diversified livelihoods were more able to adapt when income was lost from flood, drought, seasonality or poor water management. However, rural residents reported making charcoal or selling firewood that was resulting in deforestation with the potential to accelerate land degradation and exacerbate flooding.

Households within rural areas were adapting by whatever means necessary when they were in crisis. However, they had insufficient financial power (money to buy water from more expensive sources) to secure safe, reliable water access for use at home. Many of the interview respondents cited cost as the reason for not accessing safer sources, such as transporting water from the local town or buying bottled water to drink. Hence, they were often relying on surface water bodies, or shallow groundwater to fulfil their domestic water needs, irrespective of the quality of the water. This dependence was particularly high at times when rural (or urban water supply systems, when being accessed by rural communities) did not provide enough water to meet household needs. One of the most difficult challenges to manage was the uncertainty around water availability through government supply systems experienced across the basin. Most rural research participants reported not knowing when water would be available or where, resulting in a time-use and emotional burden.

"We travel around to many different sources to find water with
the mule or donkey and cart. Most of the time the children go but
sometimes I go myself. During the dry season it is more difficult
because we have to bring water for the cattle as well. In the dry
season the distance is further. Often we go at night to collect water.
We don't know which sources will be available and we do not have
telephone numbers of people in the kebeles to check. There was a
time when there was no water and we came back with an empty
barrel and we were thirsty. It happens at some point every year."
(Male farmer, upper basin woreda, December 2018)

Across all the private industrial water users surveyed, there were no challenges reported to accessing water that were not overcome. There was good access to water due to their strong financial power for investment; electricity shortages that could potentially limit water abstraction were buffered with generators. Occasional infrastructure failure was reported that had very little impact on production or staff as they switched waters sources or had the economic power to quickly address issues. Borgomeo et al. (2018) argued that the industrial sector would lose 3\% in GDP under future decreased rainfall available climate scenario in the Awash River basin. The empirical findings from this study suggest private industry would be less impacted than others due to the financial and adaptive capacity of industrial water users.

\section{Social and Cultural Power}

Considering intra-community power relations informs our understanding of equity in water security. When rural populations are considered as a homogenous group, or aggregated statistics on water coverage are used for information, the worst-case scenarios are often excluded from the narrative and gendered inequalities are hidden. Feminist approaches have been shown to be useful in revealing water-related inequities (Truelove, 2011). While many water risks may be related to place, the experience of them will differ for women, men, girls and boys. These gendered differences are shown in Table 3. This table is not comprehensive: gendered differences in responses to interview questions were drawn out and included in the table. Those water risks that significantly overlapped responses from men and women have not been included, but are discussed in the text. There were also a large number of non-water related community values collected, such as transportation, roads and land scarcity that have not been included.

In one case, a female farmer struggled to access water, in part, because the rural water supply system close to her home frequently failed due to a lack of electricity to pump groundwater. At these times, she would travel to the local town to collect water. When both the town and rural water supply systems were not 
TABLE 3 | Overview of intra-basin differences in rural experiences of water-relates risks, with embedded water-related values.

\begin{tabular}{|c|c|c|c|c|c|c|c|}
\hline \multirow{2}{*}{$\begin{array}{l}\text { Water users } \\
\text { Rural } \\
\text { Communities }\end{array}$} & \multicolumn{3}{|c|}{ Upper woreda } & \multicolumn{2}{|c|}{ Middle woreda } & \multicolumn{2}{|c|}{ Lower woreda } \\
\hline & $\begin{array}{l}\text { Fishing } \\
\text { community }\end{array}$ & $\begin{array}{l}\text { Drought-prone } \\
\text { rainfed } \\
\text { cultivators }\end{array}$ & $\begin{array}{l}\text { Flood-prone } \\
\text { irrigating } \\
\text { smallholders }\end{array}$ & $\begin{array}{l}\text { Drought prone } \\
\text { agro- } \\
\text { pastoralists }\end{array}$ & $\begin{array}{l}\text { Flood prone } \\
\text { irrigating } \\
\text { smallholders }\end{array}$ & $\begin{array}{l}\text { Settled agro- } \\
\text { pastoralists with } \\
\text { mixed } \\
\text { livelihoods: } \\
\text { livestock and } \\
\text { irrigated } \\
\text { smallholdings }\end{array}$ & $\begin{array}{l}\text { Drought-prone } \\
\text { pastoralist } \\
\text { community }\end{array}$ \\
\hline Male & $\begin{array}{l}\text { Flooding results in } \\
\text { lost farm } \\
\text { investments. } \\
\text { Feeling angry } \\
\text { during a flood. }\end{array}$ & $\begin{array}{l}\text { Drinking water } \\
\text { scarcity. } \\
\text { Climate variability } \\
\text { impacts on } \\
\text { rainfed cultivation. }\end{array}$ & $\begin{array}{l}\text { Worried about } \\
\text { food and income } \\
\text { when crops } \\
\text { destroyed by } \\
\text { flood. } \\
\text { Anxiety, fear for } \\
\text { house } \\
\text { during flood. }\end{array}$ & $\begin{array}{l}\text { Conflict over } \\
\text { rangeland during } \\
\text { drought. } \\
\text { Lake Beseka and } \\
\text { Kassam Dam have } \\
\text { consumed the } \\
\text { rangelands limiting } \\
\text { fodder access. }\end{array}$ & $\begin{array}{l}\text { Insufficient } \\
\text { irrigation. } \\
\text { Feeling like a } \\
\text { failure and weak } \\
\text { when crops } \\
\text { destroyed } \\
\text { by flood. }\end{array}$ & $\begin{array}{l}\text { Irrigation shortage } \\
\text { during drought. }\end{array}$ & $\begin{array}{l}\text { Livestock loss } \\
\text { during drought. }\end{array}$ \\
\hline Female & $\begin{array}{l}\text { Flooding: reduces } \\
\text { fish in lake; } \\
\text { Prevents livestock } \\
\text { watering; } \\
\text { Poor household } \\
\text { water quality. } \\
\text { Worry for self and } \\
\text { sadness } \\
\text { for affected. }\end{array}$ & $\begin{array}{l}\text { Huge emotional, } \\
\text { time and workload } \\
\text { burden of securing } \\
\text { income for children } \\
\text { during drought. } \\
\text { Water, food and } \\
\text { soap price hikes } \\
\text { during drought. }\end{array}$ & $\begin{array}{l}\text { Worried to buy } \\
\text { food for children } \\
\text { due to market } \\
\text { price rises during } \\
\text { drought. } \\
\text { Worried for life } \\
\text { during flood. }\end{array}$ & $\begin{array}{l}\text { During drought: } \\
\text { worry about } \\
\text { insufficient drinking } \\
\text { water and food. } \\
\text { Large workload } \\
\text { during drought } \\
\text { fetching water and } \\
\text { weak livestock }\end{array}$ & $\begin{array}{l}\text { Flooding and fear } \\
\text { for life and house. } \\
\text { Rainfed } \\
\text { farming-lack of } \\
\text { rain and } \\
\text { prosopis invasion. }\end{array}$ & $\begin{array}{l}\text { Loss of human } \\
\text { and animal lives } \\
\text { during drought. } \\
\text { High workload } \\
\text { taking livestock to } \\
\text { feed. } \\
\text { Physical health } \\
\text { impacts from } \\
\text { collecting water. }\end{array}$ & $\begin{array}{l}\text { Households } \\
\text { without a donkey } \\
\text { struggle to secure } \\
\text { household water } \\
\text { access. }\end{array}$ \\
\hline Children & $\begin{array}{l}\text { In the dry season, } \\
\text { flash floods } \\
\text { interrupt } \\
\text { schooling. } \\
\text { The well-water } \\
\text { causes illness. } \\
\text { Children unsafe } \\
\text { when collecting } \\
\text { water along the } \\
\text { busy road. }\end{array}$ & $\begin{array}{l}\text { During drought } \\
\text { school missed for } \\
\text { labour including: } \\
\text { livestock watering, } \\
\text { household and } \\
\text { private farm work. } \\
\text { Life at risk from } \\
\text { diseases such as } \\
\text { cholera. }\end{array}$ & $\begin{array}{l}\text { Flood causes } \\
\text { malaria and } \\
\text { typhoid. } \\
\text { Child labour } \\
\text { during drought. }\end{array}$ & $\begin{array}{l}\text { During drought: } \\
\text { not enough milk } \\
\text { for children's } \\
\text { nutritional needs. } \\
\text { Increase in } \\
\text { waterborne diseases. }\end{array}$ & $\begin{array}{l}\text { Flood causes: } \\
\text { interruption to } \\
\text { schooling; Malaria; } \\
\text { and Food } \\
\text { insecurity. }\end{array}$ & $\begin{array}{l}\text { Drought results in } \\
\text { an increase in } \\
\text { waterborne } \\
\text { diseases and } \\
\text { missed education. }\end{array}$ & $\begin{array}{l}\text { Child labour to } \\
\text { tend to } \\
\text { livestock-missed } \\
\text { school and high } \\
\text { workload during } \\
\text { drought. }\end{array}$ \\
\hline
\end{tabular}

operating, she had to buy bottled water at high expense. In the interview she was asked: "When you compare yourself with the community in this area, what is your level of accessing drinking water: top, medium or least?" She responded: "I don't have any jerrycans, a donkey or a cart. I have to bring water by carrying it on my back. I am the least."

We found gendered differences between lived experiences of the mental health affects of water insecurity from risks to livelihoods and household water security (Wutich et al., 2020). In line with Vins et al. (2015) we found that men experienced the emotional burden of being the household "provider" when climate shocks resulted in crop destruction or loss of livestock. Male informants reported feeling "angry" "disturbed" and "great worry." Women were primarily responsible for managing household water, a common finding in literature (Geere and Cortobius, 2017) and experienced various risks that men did not. There is existing evidence that women's mental health is adversely affected by household water insecurity (Brewis et al., 2021). Women also experience livelihood risks, for example, one fisherwoman reported:

"When I work this work, there are many issues; there are thieves waiting for you at the roadside so you fear for your physical safety and your materials may be stolen. I bought my fishing materials for around 20,000 Birr [633 USD]. If you are not watching, the [fishing] materials will be stolen because they are at the fishing site most of the time. For example [my fishing materials] have been stolen twice... There are some people who are not happy if you are strong in your work especially when you are a woman and working effectively." (Female member of fishing community, upper basin woreda, December 2018)

Children experience wide-ranging water-related health risks during drought and flood events (World Health Organisation, 2014) that include adverse effects of food insecurity (Belesova et al., 2019). One farmer revealed that her daughter had died many years before during a drought shock after contracting cholera. When discussing water-related health risks, one informant reported being ill himself from dysentery but in general, most reported that their children had become ill from typhoid or with unspecified diarrhoeal disease. Respondents talked about a lack of nutritious food for their children during times of droughts, particularly in relation to livestock who stop producing milk.

Climate shocks take children out of school and interrupt education (Randell and Gray, 2016). At a time of flood, one 
farmer revealed that he kept his son home from school for fear that it would affect his health. "He was young and sometimes we feared the bad smell from the water. You, yourself may feel that bad smell when you come here. So, it was for the health of the boy. We prevented him from going to school for this reason."

Additionally, climate shocks were resulting in children working as child labourers in homesteads as well as private farms. One farmer reported that when her crop failed in 2013, she had to find an alternative source of income. "During the drought in 2013, I worked as a daily labourer on an irrigation farm. Sometimes my 7-year-old daughter would work with me."

Overall, we found that children were typically more vulnerable to water-related risks than adults and often parents were burdened with deciding how to protect their children during climate shocks. In these two cases, difficult value- and needsbased choices were made with costs and benefits of the trade-offs. In both, education was traded in favour of health in the first example and income-generation in the second.

\section{Political Power and the Production of Water-Related Risks}

Private and state-owned industrial water users were producing risks for urban and rural dwellers with pollution and by displacing communities from the land. This is strongly related to the relative power that they hold compared to rural populations. Tanneries produce wastewater that is high in salt, chromium and nutrients, among other pollutants (Chowdhury et al., 2015). Six of the seven surveyed tanneries reported undertaking primary effluent with secondary effluent treatment systems under construction. Primary effluent treatment removes primarily solids, but suspended and dissolved pollutants remain in the effluent. The two flower farms surveyed had artificial wetlands for wastewater treatment, which have been shown to have low effectiveness for nutrient removal in other areas of Africa (Mekonnen et al., 2014). Rural dwellers had negative perceptions of the effects of industrial water users on water quality in the Awash:

\begin{abstract}
"The quality of the water in the dam is decreasing over time because of the flower farms. They dump polluted water from the farm directly into the dam. There is some change in the fish. When [the fish] are stationary in the nets for too long they start dying and decomposing. The government don't care because they are getting more money from the flower farms. The water colour becomes green like leaves, especially around [the] tannery." (Male member of fishing community, upper basin woreda, December 2018)
\end{abstract}

Community displacement by the state-owned Tendaho sugarcane farm (downstream) has resulted in a poorer perceived quality of life by rural dwellers. Pastoralist populations had little power to participate in decision-making that ultimately put their values at risk. The displacement of pastoralists in the Awash River basin in Ethiopia is not a new phenomenon-it dates back as early to the establishment of the sugar farms in the $1950 \mathrm{~s}$ (Lavers, 2012). A rural community member in the lower basin woreda reported insufficient provision of basic services after being displaced and a reduction in their quality of life.
"Our former place was better because there, we had clean water. Now we have no water. When we came to this place, the government promised that we could lead better life. However, he betrayed us and now, we have nothing." (Male pastoralist, lower basin woreda, May 2018)

Overall, water managers with more socio-cultural, financial and political power had a greater ability to be water secure. Sociocultural differences in the impact of water insecurity were reported in emotional well-being, physical health and children's education. The diverse negative impacts of water insecurity are often missing from the overarching narratives around water insecurity and poverty that focus on securing incomegenerating livelihoods and food security. For example, water policies do not include, or underemphasise values and gendered differences in lived water insecurity experiences. Moreover, uneven power relations are insufficiently engaged with by governments and practitioners developing interventions towards water security, resulting in a continued misunderstanding or inequities, meaning that they are poorly addressed.

\section{Place}

In the Awash River basin, water security is uneven in different places across the basin, between and within districts. Place is an essential element of water security as it influences exposure to differing climate conditions in the districts, the proximity of water users and managers to available water resources, the quality of those resources and exposure to risk from floods, droughts and land cover change.

\section{Inequities of Rural Water Risks Across Scales}

The risks to the water-related values of rural people varied between districts due, in part, to the proximity of water users to accessible water resources and local climate conditions. There were intra-basin differences in lived experiences of water risks between the woredas. In upstream rural areas, water resources for use at home were easily available, often on premises, due to the rich availability of shallow groundwater resources and higher average annual rainfall than downstream. In contrast to downstream areas, households did not have to travel long distances to fetch water for domestic uses. Water fetching is associated with negative health impacts (Geere et al., 2018), hence upstream there were less concerns about related physical health impacts than downstream.

In the arid downstream, rural people experienced water scarcity most of the time. In this district, women and men reported travelling up to $10 \mathrm{~h}$ to fetch water for domestic use at certain times of the year (usually May and June, see Table 2). Children were also subject to these journeys. These downstream areas experienced far greater health risks from water fetching than those upstream-reporting extreme fatigue, thirst and physical pain.

Water quality was also a risk that varied across the basin. Human health, particularly the health of children, was found to be highly valued by communities across the basin. The large quantity of shallow groundwater in the upstream woreda contained dangerously high levels of fluoride (Demelash et al., 
2019); severe and debilitating health impacts are caused over time with the accumulation of fluoride in the body by consistent consumption (Kabir et al., 2019). This was not the case in the other two study woredas. In the upstream woreda, there was only one fluoride removal treatment plant providing safe drinking water for $<10 \%$ of the woreda's population.

Waterborne diseases were reported in all three areas of the basin but were found to be more prevalent in the middle and lower areas. In particular, typhoid and dysentery were reported as posing a high risk, with children disproportionately affected. The World Food Programme office in the downstream woreda estimated that waterborne diseases posed the highest risk to life (WFP, 2018). While the specific relationship between water quality and ill-health varied across the basin, there were concerns reported about poor water quality and the risk to health by the majority of rural interviewees.

As well as upstream-downstream differences, water insecurity experiences varied over smaller scales, with intra-woreda differences being observed. In the middle basin, two kebeles within the same woreda had very different lived experiences of water insecurity; one area was chronically water scarce and one was flood-prone. The people living in these kebeles had shared values in terms of generating income and achieving food security through farming. These values were being put at risk in different ways-either with too much or too little water.

A person's physical location is strongly related to their experience of water insecurity. In a chronically water scarce kebele where rainfed farms were being cultivated, being water secure was highly connected to the rain-as one farmer said, "When it starts raining, we forget our sufferings." Conversely, in a flood-prone kebele in the same woreda, farmers were engaged in irrigated agriculture. Farms were on the banks of the Awash River with direct access to water resources for developing irrigation all year round, increasing farming output, income and food security. However, the irrigated crops were regularly destroyed by unanticipated flooding resulting in water risks.

\section{Adaptation to Place-Mediated Rural Water Risks}

Rural dwellers were maximising the protection of their values to the extent that their situation allowed. In doing so, they were making trade-offs in which risks to mitigate. In the droughtprone kebele in the middle basin woreda (agro-pastoralists), when not cultivating rainfed farms in the wet season, part of the household would migrate to a tributary of the Awash River in the dry season. This allowed access to a reliable and affordable (free) water source for people and animals as well as sufficient grazing land. Children in school and older members of the community would remain in the village.

This partial household migration allowed the protection of some of the values expressed in the area but several were still being put as risk by water insecurity. Food security, income and children's education were being protected while health and household water access remained at risk. In the village, the community had access to a single borehole that was not always functional. Those that remained in the village would have to travel long distances to access household water from a canal or a lake further afield. This was compromising the emotional wellbeing, physical health and increasing workload, primarily for the women and girls that were collecting water.

Insecure land rights due to an uncertain land tenure system (Ayano, 2018), and tacit barriers to migration (De Brauw et al., 2017) limit the agency of rural people to become water secure by changing their place. However, private and state-owned industries have choice as to where their farm or factory will be located. This gives industrial water users more opportunity to avoid place-mediated water insecurity, targeting good water access and less exposure to flood and drought risks.

\section{Place-Mediated Risks From Drought, Flood and Land-Cover Change}

In 2015, Ethiopia experienced the worst drought event in 50 years and food aid was requested for 10.2 million people for 2016, in anticipation of widespread food insecurity (FEWSNET, 2015). The drought was caused by an El Niño-Southern Oscillation (ENSO) event (Liou and Mulualem, 2019) that resulted in severely reduced rainfall in the belg rainfall season (March-May) and delayed and erratic kiremt (July-September) rainfall. Some areas of the country received up to $50 \%$ less than average rainfall (Singh et al., 2016). Resultantly, there were drought risks reported by different water users and managers from that most recent drought event during data collection.

In 2015/16, drought risks to three state-owned sugarcane farms varied across the basin; the severity of loss of farm production from drought risks increased further downstream. The most upstream sugarcane farm, Wenji, reported very little reduction in production. In Metehara (middle Awash), abstraction was reduced by nearly a third and in Tendaho (lower Awash) sugar production was reportedly halved due to insufficient water. Data from the Awash Basin Development Office (AwBDO) [known then as the Awash Basin Authority (AwBA)] revealed that the volume of water in the Tendaho dam in November 2016 was $23 \%$ of what it had been the previous year (Awash Basin Development Office, personal communication, May 2018). The state-owned sugarcane farms were adapting to some extent using groundwater and deficit irrigation but had no formal flood or drought management plans in place.

Intra-farm inequities in water-related risk experiences at sugarcane farms were closely connected to place. In irrigation schemes, the tail end users usually get less access to water than those at the head end (e.g., Mollinga, 2003). In Wenji (upstream), the small amount of lost production in 2015 occurred at the tail of the irrigation canal. Further downstream, the sugarcane farms' irrigation canals were shared by smallholder farmers at the tail end. In 2015, these smallholders reported insufficient irrigation water for cultivation, more severely affected by the drought than the sugarcane farm at the head of the canal. One smallholder farmer in the middle Awash reported, "There was a shortage of water for sugarcane-we didn't get even a small amount of water at that time for irrigation. "Smallholder farmers expressed a desire for their own irrigation canals, rather than being at the tail end of the sugarcane farm's canal. Water security of cultivators in this case is strongly connected to their place along the irrigation canal. 
In addition to drought impacts, rural and urban communities were exposed to water risks from flooding and land-cover change from the expanding Lake Beseka that varied across the basin. Crop destruction from flood was occurring most commonly upstream, by flooding events every 1-2 years. In the middle basin, the expanding lake Besaka was covering land, limiting land-based livelihoods. Moreover, the lake was expanding to cover the urban water supply infrastructure for the main town in the middle basin woreda, challenging the urban water utility's ability to deliver safe and reliable water supplies. In the middle basin and downstream, crop destruction was relatively uncommon; irrigated crops had been destroyed through insufficient water availability only once in the previous seven years. These negative livelihood impacts, reported across all three districts, were contributing to sustaining poverty and putting the reported values at risk.

Overall, place inequities are shaped by climate conditions and proximal availability and quality of water resources. Place mediates exposure to a diversity of risk including health risks (related to the quality and availability of proximal water resources), livelihood risks (related to exposure and vulnerability to flood and drought shocks) and risks to agency (the ability of people to change their place). The concept of place offers insights into the dynamics and driving forces for uneven water security across multiple scales as well as the land-water connections that mediate the agency that water managers have to improve their water security.

\section{Politics}

The Awash River basin is a microcosm of Ethiopia's developmental state; the country's national development dynamics plays out at the basin scale contributing to inequities in water security. Ethiopia follows an agricultural development-led industrialisation strategy for national economic growth and institutional power lies at the federal and regional levels. It is at these higher echelons that decisions are made that favour private industry and state enterprises and disfavour rural livelihoods (Hailu et al., 2018). In this section, we unpack the governance mechanisms and institutional arrangements that influence unequal water security within the wider political economy, highlighting how the inclusion of politics is critical for studying inequities in water security as it has explanatory power for uneven manifestations of water access and water risks.

\section{Bottlenecks to Realising Water Managers' Values}

The Awash is a transregional river basin meaning that the overall responsibility for managing the river's waters is legally mandated to the federal Awash Basin Development Office (AwBDO). However, the regions have a constitutional right to develop water resources within their administrative boundaries. This is not a unique phenomenon, Suhardiman et al. (2018) argues "river basin planning as a function of power and contested arena of power struggles." Responsibility for water resources management in the Awash basin is shared by government stakeholders at the federal and regional level, as well as at the more local level.

Broadly, federal and regional water managers expressed similar values and priorities for water resources development but there were barriers to co-ordination. In interviews with the
AwBDO, Oromia and Afar regional Water, Mineral and Energy Bureaus, we found that shared values include: (1) good water quality; (2) successful management of floods and droughts and (3) safe water access for urban and rural communities. In line with previous research (Mersha et al., 2016), we identified a lack of institutional clarity around roles and responsibilities for: (1) reducing industrial pollution, (2) drought management and (3) flood prevention, putting water managers' values at risk.

First, respondents communicated a strong appetite for reduced industrial pollution in the Awash but little action to decrease it. There were three key reasons reported by industrial water users that explained why they are not taking active steps to reducing their pollution: (1) Guidance: Private industries don't consider that there is sufficiently clear information from the government on what procedures and standards they should be meeting - especially foreign investors who reported difficulties in understanding their responsibilities. (2) Powerlessness: factories reported that if they improve their effluent/wastewater treatment and others don't then it will make no difference. (3) Deflected responsibility: blame was placed on other industries and agriculture, including farmers with smallholdings.

Institutionally, environmental protection laws and regulations are in place but poorly enforced. The institutional arrangements include the national pollution law and the legislation from the Oromo Environmental Protection Agency (EPA). They are not without difficulties in implementation: "Large- and mediumscale manufacturing industries in Ethiopia have environmental protection policies. These policies are overambitious and never fully implemented... Corporate environmental protection has not been a widely accepted concept so far" (Amare, 2019). This, within the favourable political economy, goes some way to explain how large water users are producing water-related risks for other water users despite the political action to avoid this.

Second, there is a lack of clarity around water use during a drought year and conflicting understandings of protocol. The AwBDO policy to reduce upstream irrigation in drought years aims to prevent drought risks across the basin. While state-owned sugarcane farms, who are regulated by AwBDO, reported reducing their abstraction during a drought year, private industrial water users reported not reducing their abstraction or knowing this was a policy of the AwBDO. Therefore, the values of private commercial enterprises (primarily their production processes) were not at risk during a drought year.

Efforts to prevent drought risks across the basin with preemptive water allocation reduction are not having the desired outcomes. The main responsibility for drought preparedness and prevention institutionally lies in the Disaster Planning and Preparedness Commission (DPPC) - the branch of the Ethiopian government responsible for disaster risk reduction across the country. The AwBDO, despite having a policy for reduced water allocation upstream during a drought year, lack the power and mandate to drive drought prevention forward.

Third and finally, there is no clear, legal mandate for who is responsible for investing in flood mitigation, hence flood management is institutionally fractured. The national water resources management policy highlights flood management as a key priority but does not say how or by whom (FDRE, 1999). 
Due to the constitution/legal as well as the federal/regional disconnect, organisations feel powerless and have insufficient funding to tackle the causes of flooding by themselves. We found that this is compounded by insufficient data and a lack of trust in climate forecasts.

\section{Equity in Water Policy}

Within a political economy that favours agricultural development-led industrialisation, we have found two institutional mechanisms that specifically favour water access for farms and factories. Currently, "there are no special institutional arrangements [in Awash] that protect the interests of the less privileged local communities." (Hailu et al., 2019), even though drinking water has the highest national policy priority for water resources management (FDRE, 1999). We have uncovered two key policy areas that hamper more equitable outcomes in water security.

First, we have found that water allocation for irrigation, particularly for the state-owned sugarcane farms is at the centre of water allocation planning in the Awash basin. The logic behind this is intuitive-sugarcane farms are "large water users" and domestic water users are "small water users"-therefore, it is more important to manage large quantities of water rather than small quantities. However, this directly contravenes the national water policy priority of drinking water previously mentioned, reinforcing structural inequities in water security that adversely affect less powerful water users.

Second, guidelines for water pricing in the basin are highly inequitable. Industrial water users pay $3 \mathrm{ETB} / 1,000 \mathrm{~m}^{3}$ of (untreated) water that they use $\mathrm{e}^{1}\left(0.0001 \mathrm{USD} / \mathrm{m}^{3}\right)$ whereas a rural household pays $0.5 \mathrm{ETB} / 20 \mathrm{l}$ of (untreated) water that they use $\left(0.87 \mathrm{USD} / \mathrm{m}^{3}\right)$. It is important to note that, industrial water users do incur their own infrastructure development and maintenance costs. However, this does not negate that fact that rural households are paying 8,700 times more for access to water. This pricing policy contributes to inequities in water access and is likely to reproduce them overtime.

Overall, the political economy, institutional arrangements and policy frameworks are contributing to inequities in water security in the Awash River basin. Industrial pollution is on the rise and poorly regulated while responses to mitigate risks from drought and flood events are predominantly reactive rather than pro-active across all levels. Government and non-governmental organisations are insufficiently equipped to actively engage in building institutions and strategies for preventing risks from deteriorating water quality, floods and droughts.

\section{DISCUSSION}

\section{Plural Understandings of Equity Through Embedding Values in Water Risk}

Including values in the conceptualisation of risk within a hydrosocial framing of water security offers unique insights into how inequities can be understood; where values are being

\footnotetext{
${ }^{1}$ Additionally, it has been argued that the low water fee for irrigation water is partially contributing to low water productivity in the basin (Ayana et al., 2015).
}

compromised, this offers potential indicators of degrees of inequity in water security. Equity is understood in different ways by water managers and users, strongly shaped by various waterrelated values, which offers insights for how we explore and understand the diversity of inequity in water security. What we found in the Awash River basin is that individuals living in rural areas were experiencing a regular inability to fulfil their values due to drought, flood or chronic scarcity of safe water provision. Conversely, private companies were usually able to fulfil their values. Therefore, inequities within and between water using groups can be assessed using a value-based framework.

Embedded values enable a diverse interpretation of water security, a grounding of its subjectivity and fosters an academic move towards local conceptual understandings (the latter called for by Sen and Kansal, 2019). There have been calls for the inclusion of diverse values in water security research and practice. Jepson et al. (2017) highlighted the importance of including "values about water that extend beyond, or in addition to, utilitarian ones" in hydrosocial framings of water security. Using qualitative research methods allowed research participants to identify their own values and with an analysis starting from a place of values, our case study research revealed that embedding values within ideas of water access, risk and equity enabled a diverse interpretation of water security, a grounding of its subjectivity and fosters an academic move towards local conceptual understandings.

\section{Reconciling Competing Values}

To return to where we began, Giddens (1999) argued that ameliorating risk requires managing competing values, hence a fundamentally political set of questions, which is what we have discovered to be true in the Awash River basin. Loftus (2015) noted that the mainstream water security literature fails, "to adequately politicise the processes and relationships that reproduce water inequalities". Our case study addressed this by directly exploring the role of politics and power in mediating the reproduction of inequities of water security over time.

The realisation of water-related values in the Awash River basin was being constrained by political factors and power relations across scales. Overall, we found that the values of private water users were being met due to their financial power (water flows to money) and ability to choose their place (premium land acquisition close to quality water resources); that the values of government managed water supply systems were constrained by a lack of financial power and that place was a key barrier for stateowned sugar farms to be able to protect their values. Therefore, we are left questioning how can the values of all water users be met and even, should they be met?

Values-based approaches to water governance are not new (Groenfeldt and Schmidt, 2013; Jiménez et al., 2020) and even considered an essential component of good governance (Schulz, 2019). These are seen to some extent already in the (FDRE, 1999) with a guiding (value-based) framework for water priorities mandating drinking water first, irrigation second, followed by industrial water users (and hydropower). In the over-allocated Awash River basin, we argue that all current water demands cannot be met; all current water-related values 
cannot be fulfilled. The degree of inequity between rural water users and private companies in the basin is unacceptable. Reducing the water demand is required to meet values and the redistribution of water-related risk is necessary to reduce the inequity. Including ideas of inequity alongside national policy priorities in decision making can go some way towards assessing difficult trade-offs in competing water-related values for just and sustainable outcomes.

\section{Trade-Offs in Multi-Scalar Approaches}

This study offers insights for how embedding values at multiple scales can offer an operational framework for assessing tradeoffs in decisions. Trade-offs in multi-scalar approaches to water security have been extensively studied in the literature and they are not easy to navigate. Koehler et al. (2018) have argued that the inclusion of water risks and values in policy is essential for achieving the sustainable development goals. This means that, to manage water security trade-offs in a way that protects the most vulnerable and marginalised, a consideration of values is essential.

The physical location of water users is a critical determinant of water security. In the Awash River basin, we found that inequities in water security were shaped by the place of a water user/manager in the basin, dictating their proximity to a volume of water resources of any quality and their exposure to water-related hazards. In turn, the ability of water users or managers to change their water security status was strongly mediated by their agency and relative power to change their place. This relationship between water security, power and place can go some way to emphasising natural systems in hydrosocial studies.

Overall, our framework, established with literature and case study evidence, sheds light on understanding inequities in water security. We have found that qualitative research methods allowed values to be embedded in risk offering nuanced and local understandings of inequity in water security. Reconciling competing values (political interests), at multiple scales, in the Awash River basin will not be straight forward, but equity must be considered for just and sustainable outcomes. Inequity is a core component of water security and it is vital to develop an evidence base for subjective understandings of the "acceptable" levels of inequity that constitute the realisation of water security.

\section{CONCLUSIONS}

In a context of global population growth, urbanisation and climate change, increasingly challenging trade-offs in water security will have to be made. Without explicit consideration of equity, risk and values in these trade-offs, the poor will continue to be marginalised and water security outcomes will remain unacceptably unequal. Water security is diverse, complex and uneven with inequities playing out at multiple scales. The diversity of water risks is often missing from water policies-not allowing holistic consideration of values and gendered differences in lived water insecurity experiences. This results from uneven power relations, the political economy and institutional arrangements, contributing to the reproduction of inequitable water security over time. Water security interventions need to include water-related values and address water equity explicitly to meet social development targets. To move towards an enabling environment for more equal water security, we call for the consideration of equity in trade-offs, that consider risk, (re)-oriented with embedded values, at multiple scales.

We find that (re-)orienting the concept of water risk from a physical towards a social science framing allows it to be embedded within a hydrosocial framing of water security. A hydrosocial framing is important for understanding how politics and power underpin inequitable water security, actively putting vulnerable and marginalised populations at the centre of water security. Lived experiences, perceptions and notions of equity in water security differ to water users and water managers and are strongly linked to risks. Considering multiscalar inequities together rather than separately offers a more comprehensive understanding of how equity can be employed in water security trade-offs.

Building on the existing hydrosocial framing of water security, and with case study evidence, we have revealed a multidimensional, socio-natural framework for studying the production and reproduction of unequal water security. Though based solely on one study and needing application and development across contexts, we shed light of the importance of bridging the well-established concepts of equity, risk and values. This framework can be used in the water sector, and beyond, for ascertaining contextual understandings of equity, access and risk. This framework offers a sufficiently broad foundation for similar studies in different contexts, particularly those concerned with how equity can be employed in decision-making for trade-offs in water security.

\section{DATA AVAILABILITY STATEMENT}

The raw data supporting the conclusions of this article will be made available by the authors, without undue reservation.

\section{ETHICS STATEMENT}

The studies involving human participants were reviewed and approved by University of Oxford Central University Research Ethics Committee. Written informed consent for participation was not required for this study in accordance with the national legislation and the institutional requirements.

\section{AUTHOR CONTRIBUTIONS}

CG was involved in field data collection, theory development, and writing the first draft of the paper. KC was involved in theory development, and review and revision of multiple paper drafts. TA was involved in field data collection and review and revision 
of the final paper draft. All authors contributed to the article and approved the submitted version.

\section{FUNDING}

This document is an output from the REACH programme funded by UK Aid from the UK Foreign, Commonwealth and Development Office (FCDO) for the benefit of developing countries (Programme Code 201880). This work was also supported by the UK Research and Innovation

\section{REFERENCES}

Amare, A. (2019). Corporate environmental responsibility in Ethiopia: a Case Study of the Akaki River Basin. Ecosyst. Health Sustain. 5, 57-66. doi: 10.1080/20964129.2019.1573107

AwBA (2017). Awash River Basin Strategic Plan Main Report. Amhara: Awash Basin Authority.

Ayana, M., Teklay, G., Abate, M., Eshetu, F., and Mada, M. (2015). Irrigation water pricing in Awash River Basin of Ethiopia: Evaluation of its impact on scheme-level irrigation performances and willingness to pay. Afr. J. Agric. Res. 10, 554-565. doi: 10.5897/AJAR2014.9381

Ayano, M. F. (2018). Rural land registration in Ethiopia: myths and realities. Law Soc. Rev. 52, 1060-1097. doi: 10.1111/lasr.12369

Bakker, K., and Morinville, C. (2013). The governance dimensions of water security: a review. Philos. Transact. R. Soc. A Math. Phys. Eng. Sci. 371, 20130116. doi: 10.1098/rsta.2013.0116

Beck, U. (1992). Risk Society: Towards a New Modernity. London; Thousand Oaks, CA; New Delhi: SAGE Publications.

Bekele, D., Alamirew, T., Kebede, A., Zeleke, G., and Melese, A. M. (2016). Analysis of rainfall trend and variability for agricultural water management in Awash River Basin, Ethiopia. J. Water Clim. Change 8, 127-141. doi: 10.2166/wcc.2016.044

Belesova, K., Agabiirwe, C. N., Zou, M., Phalkey, R., and Wilkinson, P. (2019). Drought exposure as a risk factor for child undernutrition in low- and middleincome countries: a systematic review and assessment of empirical evidence. Environ. Int. 131, 104973. doi: 10.1016/j.envint.2019.104973

Boelens, R., Hoogesteger, J., Swyngedouw, E., Vos, J., and Wester, P. (2016). Hydrosocial territories: a political ecology perspective. Water Int. 41, 1-14. doi: 10.1080/02508060.2016.1134898

Boelens, R., Perreault, T., and Vos, J. (eds.) (2018). Water Justice. Cambridge: Cambridge University Press.

Borgomeo, E., Vadheim, B., Woldeyes, F. B., Alamirew, T., Tamru, S., Charles, K. J., et al. (2018). The distributional and multi-sectoral impacts of rainfall shocks: Evidence from computable general equilibrium modelling for the Awash Basin, Ethiopia. Ecol. Econ. 146, 621-632. doi: 10.1016/j.ecolecon.2017.11.038

Brewis, A., Roba, K. T., Wutich, A., Manning, M., and Yousuf, J. (2021). Household water insecurity and psychological distress in Eastern Ethiopia: Unfairness and water sharing as undertheorized factors. SSM Mental Health 1, 100008. doi: 10.1016/j.ssmmh.2021.100008

Bues, A., and Theesfeld, I. (2012). Water grabbing and the role of power: Shifting water governance in the light of agricultural foreign direct investment. Water Altern. 5, 266.

Calow, R., and Mason, N. (2014). The Real Water Crisis: Inequality in a FastChanging World. London: Overseas Development Institute Framing Paper.

Chowdhury, M., Mostafa, M. G., Biswas, T. K., Mandal, A., and Saha, A. K. (2015). Characterization of the effluents from leather processing industries. Environ. Process. 2, 173-187. doi: 10.1007/s40710-015-0065-7

Cook, C., and Bakker, K. (2012). Water security: debating an emerging paradigm. Global Environ. Change 22, 94-102. doi: 10.1016/j.gloenvcha.2011.10.011

Crow, B., and Sultana, F. (2002). Gender, class, and access to water: three cases in a poor and crowded delta. Soc. Nat. Resour. 15, 709-724. doi: 10.1080/08941920290069308 through the GCRF Water Security and Sustainable Development Hub.

\section{ACKNOWLEDGMENTS}

We would like to thank Wendy Jepson, Johanna Koehler, Alan Nichol, and Dan Yeo for theoretical discussions and Marina Korzenevica-Proud for her methodological input, all of which improved the quality of this paper.

Dadson, S., Hall, J. W., Garrick, D., Sadoff, C., Grey, D., and Whittington, D. (2017). Water security, risk, and economic growth: insights from a dynamical systems model. Water Resour. Res. 53, 6425-6438. doi: 10.1002/2017WR020640 De Brauw, A., Mueller, V., and Woldehanna, T. (2017). Does internal migration improve overall well-being in Ethiopia? ${ }^{\dagger}$. J. Afr. Econ. 27, 347-365. doi: 10.1093/jae/ejx026

Degefu, F., Lakew, A., Tigabu, Y., and Teshome, K. (2013). The water quality degradation of upper Awash River, Ethiopia. Ethiop. J. Environ. Stud. Manag. 6, 58-66. doi: 10.4314/ejesm.v6i1.7

Demelash, H., Beyene, A., Abebe, Z., and Melese, A. (2019). Fluoride concentration in ground water and prevalence of dental fluorosis in Ethiopian Rift Valley: systematic review and meta-analysis. BMC Public Health 19, 1298. doi: 10.1186/s12889-019-7646-8

Desalegn, C. E., Babel, M. S., Gupta, A. D., Seleshi, B. A., and Merrey, D. (2006). Farmers' perception of water management under drought conditions in the upper Awash Basin, Ethiopia. Int. J. Water Resour. Dev. 22, 589-602. doi: 10.1080/07900620600779723

Dinka, M. O. J. W. (2017). Delineating the drainage structure and sources of groundwater flux for Lake Basaka, Central Rift Valley region of Ethiopia. Water 9, 797. doi: 10.3390/w9120797

Edossa, D. C., Babel, M. S., and Gupta, A. D. (2010). Drought analysis in the Awash river basin, Ethiopia. Water Resour. Manag. 24, 1441-1460. doi: 10.1007/s11269-009-9508-0

FDRE (1999). National Water Resources Policy. Addis Ababa: Federal Democratic Republic of Ethiopia.

FEWSNET (2015). Illustrating the Extent and Severity of the 2015 Drought. ETHIOPIA Special Report. Available online at: https:/fews.net/sites/default/ files/documents/reports/FEWS\%20NET_Ethiopia\%202015\%20Drought \%20Map\%20Book_20151217_0.pdf (accessed January 25, 2020).

Gedefaw, M., Wang, H., Yan, D., Song, X., Yan, D., Dong, G., et al. (2018). Trend analysis of climatic and hydrological variables in the Awash River Basin, Ethiopia. Water 10, 1554. doi: 10.3390/w10111554

Geere, J.-A., and Cortobius, M. (2017). Who carries the weight of water? Fetching water in rural and urban areas and the implications for water security. Water Altern. 10, 513-540.

Geere, J.-A. L., Cortobius, M., Geere, J. H., Hammer, C. C., and Hunter, P. R. (2018). Is water carriage associated with the water carrier's health? A systematic review of quantitative and qualitative evidence. 3, e000764. doi: 10.1136/bmjgh-2018-000764

Giddens, A. (1999). Risk and responsibility. Mod. Law Rev. 62, 1-10. doi: $10.1111 / 1468-2230.00188$

Goff, M., and Crow, B. (2014). What is water equity? The unfortunate consequences of a global focus on 'drinking water'. Water Int. 39, 159-171. doi: 10.1080/02508060.2014.886355

Grasham, C. F., Korzenevica, M., and Charles, K. J. (2019). On considering climate resilience in urban water security: a review of the vulnerability of the urban poor in sub-Saharan Africa. Wiley Interdiscipl. Rev. Water 6, e1344. doi: $10.1002 /$ wat 2.1344

Grey, D., and Sadoff, C. W. (2007). Sink or swim? Water security for growth and development. Water Policy 9, 545-571. doi: 10.2166/wp.2007.021

Groenfeldt, D., and Schmidt, J. J. (2013). Ethics and water governance. Ecol. Soc. 18:14. doi: 10.5751/ES-04629-180114 
Hailu, R., and Tolossa, D. (2020). Multi-stakeholder platforms: Institutional options to achieve water security in the awash basin of Ethiopia. World Dev. Perspect. 19, 100213. doi: 10.1016/j.wdp.2020. 100213

Hailu, R., Tolossa, D., and Alemu, G. (2018). Water institutions in the Awash basin of Ethiopia: the discrepancies between rhetoric and realities. Int. J River Basin Manag. 16, 107-121. doi: 10.1080/15715124.2017.1387126

Hailu, R., Tolossa, D., and Alemu, G. (2019). Water security: stakeholders' arena in the Awash River Basin of Ethiopia. Sustain. Water Resour. Manag. 5, 513-531. doi: 10.1007/s40899-017-0208-2

Hepworth, N., Hooper, V., Hellebrandt, D., and Lankford, B. (2013). What Factors Determine the Performance of Institutional Mechanisms for Water Resources Management in Developing Countries in Delivering Pro-poor Outcomes and Supporting Sustainable Economic Growth? CEE review 11-006. Collaboration for Environmental Evidence. Available online at: www.environmentalevidence.org/SR11006.html (accessed January 17, 2022).

Hirpa, F. A., Alfieri, L., Lees, T., Peng, J., Dyer, E., and Dadson, S. J. (2019). Streamflow response to climate change in the Greater Horn of Africa. Clim. Change 156, 341-363. doi: 10.1007/s10584-019-02547-x

Hoekstra, A. Y., Buurman, J., and Van Ginkel, K. C. (2018). Urban water security: a review. Environ. Res. Lett. 13, 053002. doi: 10.1088/1748-9326/aaba52

Hunter, P. R., and Fewtrell, L. (2001). Acceptable Risk. Water Quality: Guidelines, Standards and Health. Risk Assessment and Management for Water-Related Infectious Disease. London: IWA Publishing, 207-227.

IPCC (2014). Fifth Assessment Report (AR5). Cambridge: Intergovernmental Panel on Climate Change; Cambridge University Press.

Jepson, W., Budds, J., Eichelberger, L., Harris, L., Norman, E., O'reilly, K., et al. (2017). Advancing human capabilities for water security: a relational approach. Water Sec. 1, 46-52. doi: 10.1016/j.wasec.2017.07.001

Jiménez, A., Saikia, P., Gin,é, R., Avello, P., Leten, J., Liss Lymer, B., et al. (2020). Unpacking water governance: a framework for practitioners. Water 12, 827. doi: $10.3390 /$ w12030827

JMP (2019). Progress on Household Drinking Water, Sanitation and Hygiene 2000-2017. Special Focus on Inequalities. Joint Monitoring Programme. New York, NY: United Nations Children's Fund (UNICEF) and World Health Organization (WHO).

Kabir, H., Gupta, A. K., and Tripathy, S. (2019). Fluoride and human health: Systematic appraisal of sources, exposures, metabolism, and toxicity. Crit. Rev. Environ. Sci. Technol. 50, 1116-1193. doi: 10.1080/10643389.2019. 1647028

Kebede, S., and Zewdu, S. (2019). Use of $222 \mathrm{Rn}$ and $\delta 18 \mathrm{O}-\delta 2 \mathrm{H}$ isotopes in detecting the origin of water and in quantifying groundwater inflow rates in an alarmingly growing lake, Ethiopia. Water 11, 2591. doi: 10.3390/w111 22591

Koehler, J., Rayner, S., Katuva, J., Thomson, P., and Hope, R. (2018). A cultural theory of drinking water risks, values and institutional change. Global Environ. Change 50, 268-277. doi: 10.1016/j.gloenvcha.2018. 03.006

Lankford, B., Bakker, K., Zeitoun, M., and Conway, D. (2013). Water Security: Principles, Perspectives and Practices. Routledge. doi: 10.4324/97802031 13202

Lavers, T. (2012). Patterns of agrarian transformation in Ethiopia: Statemediated commercialisation and the 'land grab'. J. Peasant Stud. 39, 795-822. doi: 10.1080/03066150.2012.660147

Linton, J., and Budds, J. (2014). The hydrosocial cycle: Defining and mobilizing a relational-dialectical approach to water. Geoforum 57, 170-180. doi: 10.1016/j.geoforum.2013.10.008

Liou, Y.-A., and Mulualem, G. M. (2019). Spatio-temporal assessment of drought in Ethiopia and the impact of recent intense droughts. Remote Sens. 11, 1828. doi: $10.3390 /$ rs 11151828

Loftus, A. (2015). Water (in) security: securing the right to water. Geogr. J. 181, 350-356. doi: 10.1111/geoj.12079

Mekonnen, A., Leta, S., and Njau, K. N. (2014). Wastewater treatment performance efficiency of constructed wetlands in African countries: a review. Water Sci. Technol. 71, 1-8. doi: 10.2166/wst.2014.483

Mersha, A., Masih, I., De Fraiture, C., Wenninger, J., and Alamirew, T. (2018). Evaluating the impacts of IWRM policy actions on demand satisfaction and downstream water availability in the upper Awash Basin, Ethiopia. Water 10, 892. doi: 10.3390/w10070892

Mersha, A. N., De Fraiture, C., Mehari, A., Masih, I., and Alamirew, T. (2016). Integrated water resources management: contrasting principles, policy, and practice, Awash River Basin, Ethiopia. Water Policy 18, 335-354. doi: 10.2166/wp.2015.049

Mollinga, P. P. (2003). On the Waterfront: Water Distribution, Technology and Agrarian Change in a South Indian Canal Irrigation System. Wageningen: Orient Blackswan.

Mosello, B., Calow, R., Tucker, J., Parker, H., Alamirew, T., Kebede, S., et al. (2015). Building Adaptive Water Resources Management in Ethiopia. London: Overseas Development Institute.

Nofal, O. M., and Van De Lindt, J. W. (2020). Understanding flood risk in the context of community resilience modeling for the built environment: research needs and trends. Sustain. Resilient Infrastruct. 1-17. doi: $10.1080 / 23789689.2020 .1722546$

Oulahen, G. (2021). Flood hazards, environmental rewards, and the social reproduction of risk. Geoforum 119, 43-51. doi: $10.1016 /$ j.geoforum.2020.12.021

Perreault, T. (2014). What kind of governance for what kind of equity? Towards a theorization of justice in water governance. Water Int. 39, 233-245. doi: $10.1080 / 02508060.2014 .886843$

Randell, H., and Gray, C. (2016). Climate variability and educational attainment: evidence from rural Ethiopia. Global Environ. Change 41, 111-123. doi: 10.1016/j.gloenvcha.2016.09.006

Rusca, M., and Di Baldassarre, G. (2019). Interdisciplinary critical geographies of water: capturing the mutual shaping of society and hydrological flows. Water 11, 1973. doi: 10.3390/w11101973

Savelli, E., Rusca, M., Cloke, H., and Di Baldassarre, G. (2021). Don't blame the rain: social power and the 2015-2017 drought in Cape Town. J. Hydrol. 594, 125953. doi: 10.1016/j.jhydrol.2020.125953

Schulz, C. (2019). Governance-related values as dimensions of good water governance. Wiley Interdiscipl. Rev. Water 6, e1322. doi: 10.1002/wat 2.1322

Semela, T., Bekele, H., and Abraham, R. (2019). Women and development in Ethiopia: a sociohistorical analysis. J. Dev. Soc. 35, 230-255. doi: $10.1177 / 0169796 \mathrm{X} 19844438$

Sen, S. M., and Kansal, A. (2019). Achieving water security in rural Indian Himalayas: a participatory account of challenges and potential solutions. $J$. Environ. Manage. 245, 398-408. doi: 10.1016/j.jenvman.2019.05.132

Singh, R., Worku, M., Bogale, S., Cullis, A., Adem, A., Irwin, B., et al. (2016). Reality of resilience: perspectives of the 2015-16 drought in Ethiopia. BRACED Resilience Intel. 6, 1-28. Available online at: https://www.preventionweb.net/ files/51332_resilienceintelethiopiapaperweb.pdf (accessed January 17, 2022).

Sivapalan, M., Savenije, H. H., and Blöschl, G. (2012). Socio-hydrology: a new science of people and water. Hydrol. Process. 26, 1270-1276. doi: 10.1002/hyp. 8426

Srinivasan, V., Konar, M., and Sivapalan, M. (2017). A dynamic framework for water security. Water Sec. 1, 12-20. doi: 10.1016/j.wasec.2017.03.001

Strang, V. (2016). Infrastructural relations: water, political power and the rise of a new 'despotic regime'. Water Altern. 9, 292-318.

Suhardiman, D., Bastakoti, R. C., Karki, E., and Luna, B. (2018). The politics of river basin planning and state transformation processes in Nepal. Geoforum 96, 70-76. doi: 10.1016/j.geoforum.2018.07.019

Swyngedouw, E. (2004). Social Power and the Urbanization of Water: Flows of Power. Oxford: Oxford University Press.

Swyngedouw, E. (2009). The political economy and political ecology of the hydro-social cycle. J. Contemp. Water Res. Educ. 142, 56-60. doi: 10.1111/j.1936-704X.2009.00054.x

Taye, M., Dyer, E., Hirpa, F., and Charles, K. (2018). Climate change impact on water resources in the Awash basin, Ethiopia. Water 10, 1560. doi: 10.3390/w10111560

Truelove, Y. (2011). (Re-)Conceptualizing water inequality in Delhi, India through a feminist political ecology framework. Geoforum 42, 143-152. doi: 10.1016/j.geoforum.2011.01.004

Truelove, Y. (2019). Rethinking water insecurity, inequality and infrastructure through an embodied urban political ecology. Wiley Interdiscipl. Rev. Water 6, e1342. doi: 10.1002/wat2.1342 
UN (2019a). The Sustainable Development Goals Report 2019. New York, NY: United Nations.

UN (2019b). World Populations Prospects 2019. New York, NY: DESA; United Nations.

Vins, H., Bell, J., Saha, S., and Hess, J. J. (2015). The mental health outcomes of drought: a systematic review and causal process diagram. Int. J. Environ. Res. Public Health 12, 13251-13275. doi: 10.3390/ijerph121013251

Wada, Y., Gain, A., and Giupponi, C. (2016). Measuring global water security towards sustainable development goals. Environ. Res. Lett. 11, 2-13. doi: 10.1088/1748-9326/11/12/124015

Wesselink, A., Kooy, M., and Warner, J. (2017). Socio-hydrology and hydrosocial analysis: toward dialogues across disciplines. Wiley Interdiscipl. Rev. Water 4, e1196. doi: 10.1002/wat2.1196

WFP (2018). Report on Drought Risks in Dubti Woreda. Afar: UN World Food Programme.

Wondim, Y. K. (2016). Flood hazard and risk assessment using GIS and remote sensing in lower Awash sub-basin, Ethiopia. J. Environ. Earth Sci. 6, 69-85.

Woodhouse, P., and Muller, M. (2017). Water governance-An historical perspective on current debates. World Dev. 92, 225-241. doi: 10.1016/j.worlddev.2016.11.014

World Health Organisation (2014). Quantitative Risk Assessment of the Effects of Climate Change on Selected Causes of Death, 2030s and 2050s. Switzerland.

Wutich, A., Brewis, A., and Tsai, A. (2020). Water and mental health. Wiley Interdiscipl. Rev. Water 7, e1461. doi: 10.1002/wat2.1461

Wutich, A., Budds, J., Eichelberger, L., Geere, J., Harris, L. M., Horney, J. A., et al. (2017). Advancing methods for research on household water insecurity: Studying entitlements and capabilities, socio-cultural dynamics, and political processes, institutions and governance. Water Sec. 2, 1-10. doi: 10.1016/j.wasec.2017.09.001

Yates, J. S., Harris, L. M., and Wilson, N. J. (2017). Multiple ontologies of water: politics, conflict and implications for governance. Environ. Plann. D Soc. Space 35, 797-815. doi: 10.1177/0263775817700395

Yihdego, Z., Rieu-Clarke, A., and Cascão, A. E. (2017). The Grand Ethiopian Renaissance Dam and the Nile Basin: Implications for Transboundary Water Cooperation. Routledge.
Zeitoun, M. (2011). The global web of national water security. Global Policy 2, 286-296. doi: 10.1111/j.1758-5899.2011.00 097.x

Zeitoun, M., Lankford, B., Krueger, T., Forsyth, T., Carter, R., Hoekstra, A. Y., et al. (2016). Reductionist and integrative research approaches to complex water security policy challenges. Global Environ. Change 39, 143-154. doi: 10.1016/j.gloenvcha.2016. 04.010

Zwarteveen, M., Kemerink-Seyoum, J. S., Kooy, M., Evers, J., Guerrero, T. A., Batubara, B., et al. (2017). Engaging with the politics of water governance. Wiley Interdiscipl. Rev. Water 4, e1245. doi: 10.1002/wat2. 1245

Author Disclaimer: The views expressed and information contained in it are not necessarily those of or endorsed by FCDO, which can accept no responsibility for such views or information or for any reliance placed on them.

Conflict of Interest: The authors declare that the research was conducted in the absence of any commercial or financial relationships that could be construed as a potential conflict of interest.

Publisher's Note: All claims expressed in this article are solely those of the authors and do not necessarily represent those of their affiliated organizations, or those of the publisher, the editors and the reviewers. Any product that may be evaluated in this article, or claim that may be made by its manufacturer, is not guaranteed or endorsed by the publisher.

Copyright (c) 2022 Grasham, Charles and Abdi. This is an open-access article distributed under the terms of the Creative Commons Attribution License (CC BY). The use, distribution or reproduction in other forums is permitted, provided the original author(s) and the copyright owner(s) are credited and that the original publication in this journal is cited, in accordance with accepted academic practice. No use, distribution or reproduction is permitted which does not comply with these terms. 